\title{
Solitary cerebellar metastasis from bladder cancer
}

\author{
Pojedynczy przerzut móżdżkowy jako pierwotna manifestacja \\ raka pęcherza moczowego
}

Konrad Majcherczyk (D) Mateusz Marcinek, Marcel Nowak, Michał Tkocz

Department of Urology, Faculty of Medical Sciences in Katowice, Medical University of Silesia, Katowice, Poland

\begin{abstract}
Brain metastases are quite rare in the course of bladder cancer and occur in only $1-7 \%$ of these patients. In most cases, cerebral metastases are secondary to visceral and lymph node metastases. A single cerebellar metastasis as the primary manifestation of transitional cell carcinoma (TCC) has only been reported in few cases. A 55-year-old man presented to the hospital with persistent headaches, accompanied by nausea and balance disturbance lasting for three weeks. Computed tomography (CT) of the head revealed a nodular lesion measuring $28 \times 24 \times 22 \mathrm{~mm}$ in diameter, located in the cerebellar vermis. Subsequently, a CT scan conducted of the chest, abdominal cavity and lesser pelvis revealed a tumor in the urinary bladder with concomitant right hydronephrosis. No lymphadenopathy nor signs of other metastases were found. Craniotomy with complete tumor resection and external ventricular drainage was performed. The patient underwent transurethral electroresection of the bladder tumor involving the right part of the bladder trigone with the right ureteral orifice and the right bladder wall. The histopathological and immunohistochemical examination of both the cerebellar and bladder tumors confirmed high grade muscle invasive bladder cancer (T2, HG). Based on these findings, the patient was diagnosed with cerebellar metastasis from primary bladder cancer. The patient did not consent to the proposed cystectomy and was transferred to the oncology department where he was qualified for brain and pelvic radiotherapy and subsequent systemic chemotherapy.
\end{abstract}

This case is an example that bladder cancer (stage T2) may develop without urologic symptoms.

KEY WORDS

bladder cancer, central nervous system, transitional cell carcinoma, cerebellar metastasis

\section{STRESZCZENIE}

Pośród pacjentów z rakiem pęcherza moczowego przerzuty do mózgu są rzadko spotykane i dotyczą około 1-7\% chorych z naciekającym rakiem pęcherza. W większości przypadków przerzuty mózgowe są wtórne do obecnych już przerzutów w narządach trzewnych i węzłach chłonnych. Pierwotna manifestacja raka przejściowokomórkowego (transitional cell carcinoma - TCC) jako pojedynczy przerzut móżdżkowy została opisana w pojedynczych artykułach. Mężczyzna 55-letni zgłosił się do szpitala z powodu uporczywych dolegliwości bólowych głowy z towarzyszącymi nudnościami. Objawom towarzyszyły zaburzenia równowagi. Tomografia komputerowa (TK) głowy wykazała obecność zmiany guzowatej o wymiarach 28 × 24 x 22 mm w górnej części robaka móżdżku. Badanie TK klatki piersiowej, jamy brzusznej

\begin{tabular}{|c|c|c|}
\hline Received: 09.11.2020 & Accepted: 25.10 .2021 & Published online: 30.12 .2021 \\
\hline
\end{tabular}

Copyright @ Śląski Uniwersytet Medyczny w Katowicach www.annales.sum.edu.pl 
i miednicy małej uwidoczniło zmianę guzowatą w obrębie pęcherza moczowego z poszerzeniem układu kielichowo-miedniczkowego nerki prawej. Nie stwierdzono powiększonych węzłów chłonnych ani cech innych przerzutów. Wykonano kraniotomię i zewnętrzny drenaż komór mózgu, usuwając guz. Pacjenta zakwalifikowano do przezcewkowej elektroresekcji zmiany guzowatej w obrębie pęcherza. Guz obejmował część trójkąta pęcherza moczowego wraz z ujściem prawego moczowodu i większą część prawej ściany pęcherza. Badania histopatologiczne i immunohistochemiczne obu tkanek guzowatych (móżdżku i pęcherza) potwierdziły obecność komórek raka przejściowokomórkowego o wysokim stopniu złośliwości (high grade - HG) z inwazją mięśniową w obrębie wypieracza pęcherza (T2, HG). Na tej podstawie u chorego rozpoznano naciekającego raka pęcherza z przerzutem do móżdżku. Pacjent nie wyraził zgody na cystektomię i został przekazany na oddział onkologii, gdzie zakwalifikowano go do radioterapii głowy i miednicy oraz następowej chemioterapii.

W pracy opisano przypadek rozległego guza pęcherza moczowego T2, który rozwinął się bez typowych objawów urologicznych.

\section{SŁOWA KLUCZOWE}

rak pęcherza, ośrodkowy układ nerwowy, rak przejściowokomórkowy, przerzut móżdżkowy

\section{INTRODUCTION}

Bladder cancer is the most prevalent malignancies of the urinary tract. In Poland in 2018 a total of 7494 new cases of bladder cancer (5612 men and 1882 women) was registered, which corresponds to $6.7 \%$ male and $2.2 \%$ female malignant neoplasms.

The worldwide age-standardized incidence rates (ASRs) from bladder cancer is 9.1 per 100000 for men and 2.2 per 100000 for women. In Europe, the highest incidence of bladder cancer was reported in the western region (17.4 in men and 4.4 in women) and in the southern region (20.7 in men and 6.2 in women), followed by northern Europe (13.7 in men and 4.7 in women). The lowest incidence was observed in eastern European regions (14.7 in men and 6.5 in women). The global world mortality rate is 3.3 per 100000 for men and 0.9 per 100000 for women. In Europe bladder cancer mortality rates have declined over the last decade to about $16 \%$ for men and $12 \%$ for women. The highest mortality rate in Europe is in Poland (8.0 per 100000 for men) $[3,4]$.

\section{CASE REPORT}

A 55-year-old man was admitted to the Hospital Emergency Unit with persistent headaches, dizziness, impaired coordination and balance lasting for three weeks. A moderately elevated creatinine level $(1.5 \mathrm{md} / \mathrm{dl}, \mathrm{N}: 0.8-1.4 \mathrm{mg} / \mathrm{dl})$ and erythrocyturia were found in the laboratory results. Unilateral ataxia (left upper limb semiataxia) with a positive Romberg test and unsteady gait were the outcomes of a neurological examination. In consequence, computed tomography (CT) and magnetic resonance imaging (MRI) scans of the central nervous system were performed, which revealed a tumor $28 \times 24 \times 22 \mathrm{~mm}$ located in the cerebellar vermis with edema involving both hemispheres of the cerebellum, causing stenosis of the fourth ventricle with cerebral aqueduct compression and widening of the lateral ventricles (Figure 1).
The patient was admitted to the Neurological Department where the whole body CT was conducted. A lesion in the urinary bladder was revealed with right side hydronephrosis (Figure 2); however, no lymphadenopathy nor metastases to other organs were found. The bladder tumor was also assessed by ultrasound scanning. After antiedema treatment was administered, the imbalance and also pain were reduced. The patient was qualified by a neurosurgeon for a suboccipital median craniotomy with external ventricular drainage. Tumor resection was complete. High grade $(\mathrm{HG})$ urothelial carcinoma was diagnosed by histological examination of the cerebellar tumor (Figure 3). Scanning speech occurred during the postoperative period but no hydrocephalus nor intracranial hypertension features were present. Remarkable improvement in the patient's quality of life was observed.

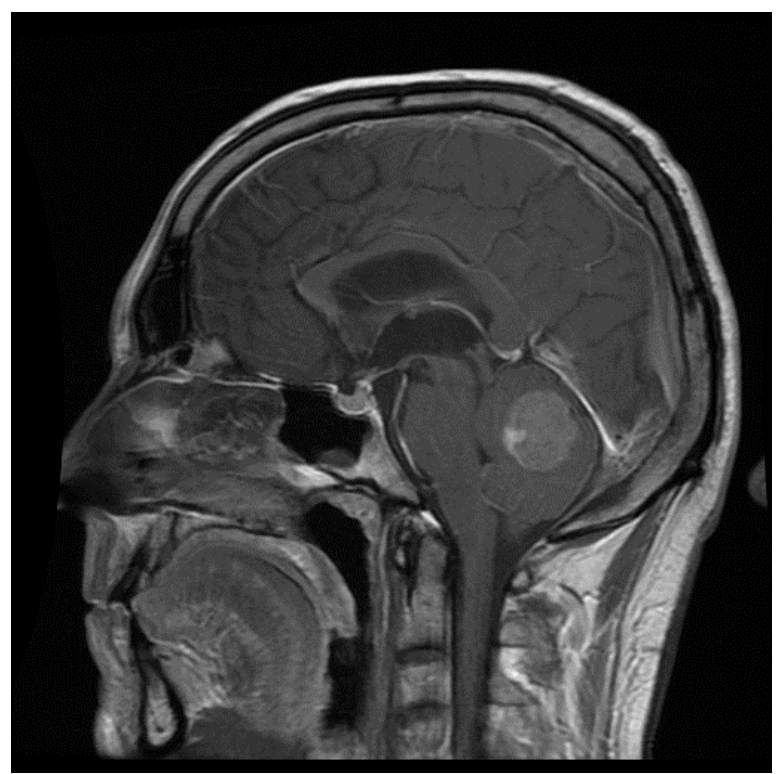

Fig. 1. Brain MRI showing mass lesion located in cerebellum vermis. Ryc. 1. Rezonans magnetyczny głowy, widoczna zmiana guzowata w obrębie robaka móżdżku. 


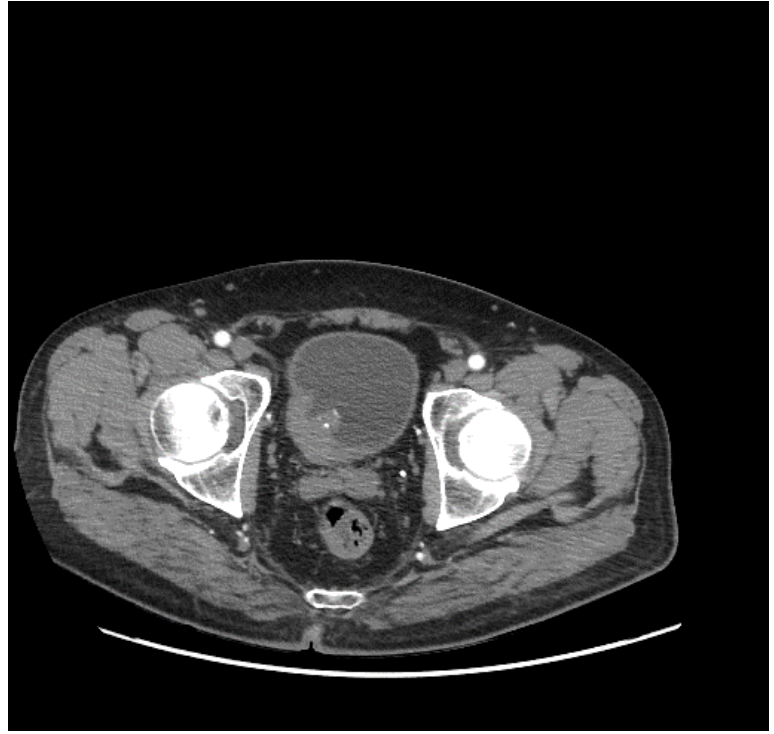

Fig. 2. Enhanced pelvic CT revealing heterogeneous mass $50 \mathrm{~mm}$ in diameter which indented bladder.

Ryc. 2. Tomografia komputerowa miednicy małej ze wzmocnieniem kontrastowym, ukazująca niejednorodną zmianę guzowatą pęcherza moczowego o średnicy $50 \mathrm{~mm}$.

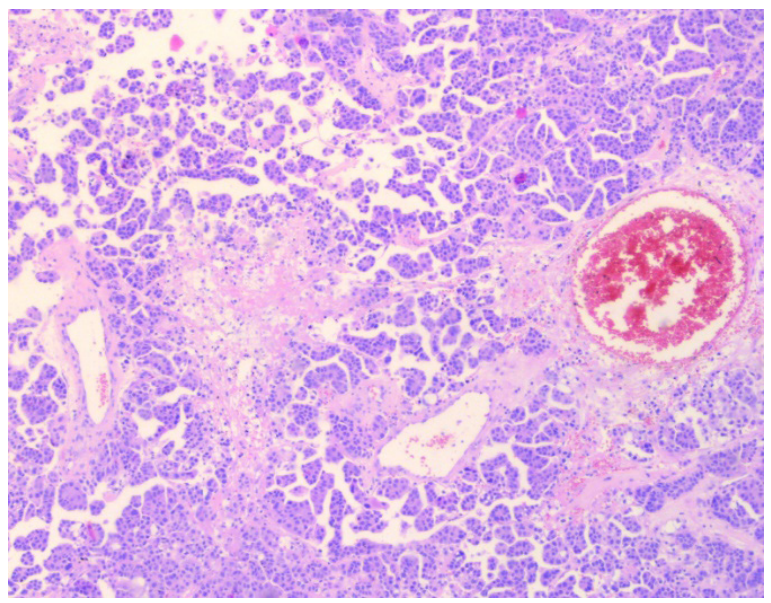

Fig. 3. Microphotograph of brain mass revealing metastatic carcinoma of bladder.

Ryc. 3. Obraz mikroskopowy zmiany przerzutowej raka pęcherza moczowego do mózgu.

The patient was admitted to the Urology Ward after three weeks where he underwent transurethral electroresection of the bladder tumor involving the right part of the bladder trigone with the right ureteral orifice and the right bladder wall. The histopathological and immunohistochemical examination of the bladder tumor revealed $\mathrm{HG}$ muscle invasive transitional cell carcinoma - TCC (T2, HG; Figure 4), which corresponded to the histological evaluation of the cerebellar tumor. As a result, a cerebellar metastasis from primary bladder cancer was diagnosed. The patient did not consent to proposed cystectomy and was transferred to the Oncology Ward for brain and pelvic radiotherapy and further systemic chemotherapy.

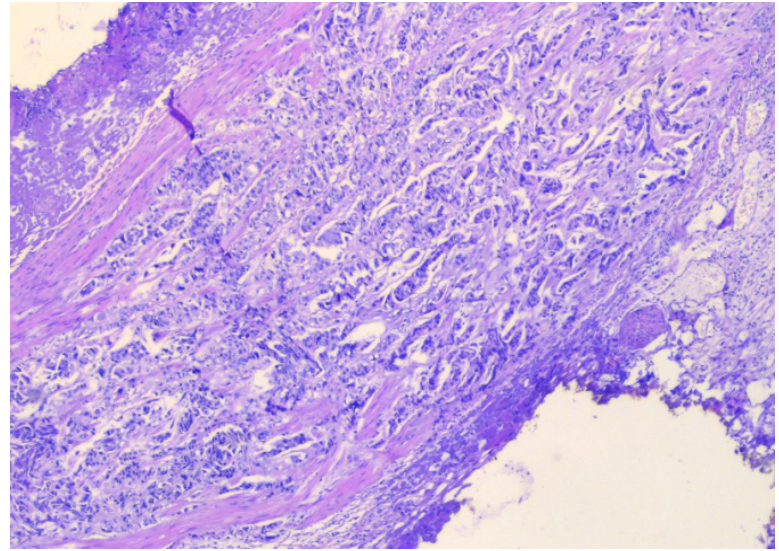

Fig. 4. Microphotograph of bladder tumor revealing muscle invasive TCC. Ryc. 4. Obraz mikroskopwy raka pęcherza moczowego naciekającego mięśniówkę właściwa.

The patient is under regular urological observation. The scanning speech is still present; there are no signs of developing renal insufficiency.

\section{DISCUSSION}

The presented case is an example of an asymptomatic bladder tumor manifested only by symptoms associated with metastasis to the cerebellum. Although in approximately $75-85 \%$ of patients bladder cancer is confined to the mucosa (Ta or CIS) or submucosa (T1), it has a propensity to recur $(70 \%$ at 3 years). Between $10 \%$ to $20 \%$ of these recurrences may progress to invasive disease $[5,6,7]$.

The most common adult primary tumors that metastasize to the brain, in decreasing order of frequency are lung, breast, skin (melanoma), renal, and colon cancers [8]. A retrospective study of 392 patients with urinary bladder cancer reported that the most common sites of metastasis were the lymph nodes (104 patients, 69\%) followed by bone (71 patients, 47\%), lung (55 patients, 37\%), liver (39 patients, 26\%), and peritoneum (24 patients, 16\%) [9]. Brain metastasis was observed only in $7(5 \%)$ cases. Sarmiento et al. [10] revealed 290 reported cases of TCC metastasis to the central nervous system (brain parenchyma, meninges, spine, orbital/ocular). Intracranial metastases of TCC of the urinary bladder (cerebrum 21 i.e. 38.9\%, meninges 24 i.e. $44.4 \%$ and only 7 cases i.e. $13 \%$ to the cerebellum) were reported 54 times [10]. Of these, the clinical presentation of central nervous system symptoms from intracranial metastasis preceded the diagnosis of urinary bladder cancer in 11 cases $(20.4 \%)$.

Thus, solitary bladder cancer metastasis to the cerebellum is very rare. To date, in the available literature we found only a few cases $[11,12,13,14$, $15,16]$.

Tsugu et al. [17] suggest that the low frequency of brain metastases in patients with bladder cancer may indicate a lack of metastatic potential for the brain. Moreover, 
the liver and lung act as filters to the right side of the heart, and this filtering before systemic circulation is probably partly responsible for the low incidence of metastasis to the brain [17].

Common neurologic symptoms in patients with TCC intracranial metastasis include headache, nausea, vomiting, speech impairment, ataxia, cognitive impairment, dizziness and hemiparesis.

Review of the literature reveals that most patients with metastases to the central nervous system were identified after urinary bladder cancer was diagnosed. Nevertheless, in the presented case there was no clinical evidence of urinary bladder cancer before the cerebellar lesion was diagnosed. Once metastasis to the central nervous system occurs, the prognosis is very poor with most patients surviving less than 6 months. It should be emphasized that both our patient and the one presented by Shamdas et al. [11] denied any hematuria or other urologic symptoms. Similarly, Perlmutter et al. [14] presented a patient with isolated cerebellar metastasis with organ-confined, lymph node negative bladder cancer.

Hematogenous metastasis most often occurs in the lungs, liver, and bones [6]. In our case, the lack of evident features of metastasis to the regional lymph nodes suggests the hematogenous mechanism of metastasis to the cerebellum.

Nodal metastases occur in $30 \%$ of tumors involving the bladder wall and in $60 \%$ of tumors with extravesical invasion. At first metastases appear in the perivesical, sacral, presacral, hypogastric, obturator and external iliac nodal groups, then spread to the common iliac chain and the paraaortic lymph nodes, considered as distant metastasis [18]. It was observed that CT and MRI have similar rates of accuracy for nodal pelvic staging, which was $70-97 \%$ for CT and $73-98 \%$ for MRI [19].
It was reported that the dynamic contrast enhancement characteristics of lymph nodes using contrast-enhanced MRI may improve the accuracy of evaluation as most metastatic lymph nodes often take up the contrast agent more rapidly than hyperplastic or nonmetastatic lymph nodes [20]. Also, using MRI contrast agents with ultra-small iron oxide particles could be efficient (sensitivity $87 \%$ and specificity 92\%) [21]. Fluorodeoxyglucose-positron emission tomography (FDG-PET) provides only 67\% sensitivity, 86\% specificity and $80 \%$ accuracy rates for the detection of nodal metastases as demonstrated Bachor et al. [21]. In our opinion, although there is no firm guidance on this issue, regular, periodic ultrasound examination of the abdomen is a very useful tool for diagnosing asymptomatic bladder cancer.

The prognosis for patients with brain metastasis from urinary bladder cancer is poor, regardless of the treatment. Treated patients have a median survival of 2-4 months [22,23], while untreated patients' survival ranges from several days to 1.75 months $[22,24]$.

To date, routine neuroimaging screening is not performed on patients with a past history of urinary bladder cancer. Neuroimaging is undertaken generally only when symptoms such as headaches, seizures or focal deficits are present. This may lead to a lower frequency of brain metastases being detected [17].

\section{CONCLUSION}

It is observed that bladder cancer (stage 2) may develop without urologic symptoms. Bladder carcinoma metastasis should be considered in the differential diagnosis of isolated intracranial tumors. The prognosis is uncertain in such cases.

\section{Author's contribution}

Study design - K. Majcherczyk, M. Marcinek, M. Nowak, M. Tkocz

Manuscript preparation - K. Majcherczyk, M. Nowak

Literature research - K. Majcherczyk, M. Marcinek, M. Nowak

Final approval of the version to be published - K. Majcherczyk, M. Tkocz

\section{REFERENCES}

1. Wojciechowska U., Didkowska J., Zatoński W. Cancer in Poland in 2012. Centrum Onkologii - Instytut im. M. Skłodowskiej-Curie. Warsaw 2014, p. $51-113$.

2. Jabłonowski Z. Urinary bladder cancer - epidemiology, diagnostics and treatment in XXIst century [Article in Polish]. Folia Med. Lodz. 2013; 40(1): $31-52$.

3. Burger M., Catto J.W., Dalbagni G., Grossman H.B., Herr H., Karakiewicz P. et al. Epidemiology and risk factors of urothelial bladder cancer. Eur. Urol. 2013; 63(2): 234-241, doi: 10.1016/j.eururo.2012.07.033.

4. Ferlay J., Shin H.R., Bray F., Forman D., Mathers C., Parkin D.M. Estimates of worldwide burden of cancer in 2008: GLOBOCAN 2008. Int. J. Cancer 2010; 127(12): 2893-2917, doi: 10.1002/ijc.25516.

5. Stenzl A., Cowan N.C., De Santis M., Kuczyk M.A., Merseburger A.S. Ribal M.J. et al. Treatment of muscle-invasive and metastatic bladder cancer: update of the EAU guidelines. Eur. Urol. 2011; 59(6): 1009-1018, doi: 10.1016/j.eururo.2011.03.023

6. Vikram R., Sandler C.M., Ng C.S. Imaging and staging of transitional cell carcinoma: part 1, lower urinary tract. AJR Am. J. Roentgenol. 2009; 192(6): 1481-1487, doi: 10.2214/AJR.08.1318.

7. Urinary bladder. (Urological tumours). In: TNM classification of malignant tumours. L.H. Sobin, M.K. Gospodarowicz, C. Wittekind [ed.]. $7^{\text {th }}$ ed. Wiley-Blackwell. New York 2009, p. 262-265.

8. Klos K.J., O’Neill B.P. Brain metastases. Neurologist 2004; 10(1): 31-46, doi: $10.1097 / 01 \mathrm{nrl} 000010692283090.71$

9. Shinagare A.B., Ramaiya N.H., Jagannathan J.P., Fennessy F.M., Taplin M.E., Van den Abbeele A.D. Metastatic pattern of bladder cancer: correlation with the characteristics of the primary tumor. AJR Am. J. Roentgenol. 2011; 196(1): 117-122, doi: 10.2214/AJR.10.5036. 
10. Sarmiento J.M., Wi M.S., Piao Z., Stiner E.S. Solitary cerebra metastasis from transitional cell carcinoma after a 14-year remission of urinary bladder cancer treated with gemcitabine: Case report and literature review. Surg. Neurol. Int. 2012; 3: 82, doi: 10.4103/2152-7806.99172.

11. Shamdas G.J., McLaren G.D., Grimm T., Everson L.K. Solitary cerebella metastasis from transitional cell carcinoma of bladder. Urology 1992; 40(1): 50-53, doi: 10.1016/0090-4295(92)90436-Z.

12. Davies B.J., Bastacky S., Chung S.Y. Large cerebellar lesion as origina manifestation of transitional cell carcinoma of the bladder. Urology 2003 62(4): 749, doi: 10.1016/s0090-4295(03)00662-9.

13. Kobayashi T., Ogura K., Nishizawa K., Ono M., Ueno Y., Miyake H., Ide Y. Clinically isolated cerebellar metastasis of renal pelvic urothelial cancer. Int. J. Urol. 2004; 11(1): 47-49, doi: 10.1111/j.1442-2042.2004.00735.x.

14. Perlmutter A.E., Zaitoon A., Sparks S.S., Zaslau S., Zaitoon M. Isolated cerebellar metastasis in a patient with organ-confined, lymph node negative bladder cancer. W. V. Med. J. 2006; 102(5): 14-15.

15. D'Souza N., Khan M.J., Robinson S., Motiwala H. A rare and unusual case of isolated cerebellar metastasis from a non-muscle invasive transitional cell carcinoma of bladder. JRSM Short Rep. 2011; 2(6): 50, doi: 10.1258/shorts.2011.011014.

16. Vaa B., Kohli M., Price K.A., Swetz K.M. Solitary cystic cerebella metastasis in a patient with invasive transitional cell carcinoma of the bladder. BMJ Case Rep. 2014; 2014: bcr2013200137, doi: 10.1136/bcr-2013-200137.
17. Tsugu A., Yoshiyama M., Matsumae M. Brain metastasis from large cell neuroendocrine carcinoma of the urinary bladder. Surg. Neurol. Int. 2011; 2: 84, doi: $10.4103 / 2152-7806.82250$.

18. MacVicar A.D. Bladder cancer staging. BJU Int. 2000; 86 Suppl 1: 111-122, doi: 10.1046/j.1464-410x.2000.00589.x.

19. Hofer C., Kübler H., Hartung R., Breul J., Avril N. Diagnosis and monitoring of urological tumors using positron emission tomography. Eur. Urol. 2001; 40(5): 481-487, doi: 10.1159/000049823.

20. Barentsz J.O., Jager G.J., Witjes J.A. MR imaging of the urinary bladder. Magn. Reson. Imaging Clin. N. Am. 2000; 8(4): 853-867.

21. Bachor R., Kotzerke J., Reske S.N., Hautmann R. Lymph node staging of bladder neck carcinoma with positron emission tomography [Article in German]. Urologe A 1999; 38(1): 46-50, doi: 10.1007/s001200050244.

22. Mahmoud-Ahmed A.S., Suh J.H., Kupelian P.A., Klein E.A., Peereboom D.M., Dreicer R., Barnett G.H. Brain metastases from bladder carcinoma: presentation, treatment and survival. J. Urol. 2002; 167(6): 2419-2422.

23. Rosenstein M., Wallner K., Scher H., Sternberg C.N. Treatment of brain metastases from bladder cancer. J. Urol. 1993; 149(3): 480-483, doi: 10.1016/s0022-5347(17)36123-2

24. Anderson R.S., el-Mahdi A.M., Kuban D.A., Higgins E.M. Brain metastases from transitional cell carcinoma of urinary bladder. Urology 1992; 39(1): 17-20, doi: 10.1016/0090-4295(92)90034-t 